\title{
Hydroxyapatite synthesize from Pugilina cochlidium and Babylonia spirata, $L$ shells as bone graft materials candidates in periodontics
}

\author{
Aini Hariyani Nasution, Rini Octavia Nasution, \\ Desy Marlyn Situmorang, Andrie Harmaji \\ 1. Periodontics Department, Faculty of Dentistry, Universitas Sumatera Utara, Medan, Indonesia \\ Metallurgical Engineering, Institut Teknologi dan Sains Bandung, Cikarang, Indonesia
}

E-mail: ainina.dentist@gmail.com

Manuscript Information:

\section{Received}

17 January 2021

Revised

1 February 2021

Accepted

23 February 2021

Published

28 February 2021

\begin{abstract}
Hydroxyapatite has been widely used as bone graft materials in periodontics. However, hydroxyapatite is still considered costly, and many of them are imported. Hydroxyapatite manufacturers from natural sources could be an affordable alternative for periodontal regeneration therapy. Pugilina cochlidium and Babylonia spirata, L are the natural sources with high calcium carbonate. The two clamshells are easily found in Indonesia but their usage is still limited as hydroxyapatite materials. This study aims to synthesize the hydroxyapatite with sol-gel method from Pugilina cochlidium and Babylonia spirata, $\mathrm{L}$ as bone graft materials candidates.
\end{abstract}

Keywords: hydroxyapatite; periodontal regeneration therapy; calcium carbonate

\section{INTRODUCTION}

Periodontal disease with alveolar bone damage requires more attention in its treatment to prevent further bone resorption [1]. Treatment of alveolar bone resorption can be done with periodontal regeneration therapy, such as bone grafting. Currently, the most widely used synthetic material for bone grafting is in the form of bioceramics called hydroxyapatite [2]. Hydroxyapatite (HA), Ca10(PO4)6(OH)2, is essential inorganic biomaterials that have chemical and structural similarities to the bones and teeth mineral phases, making hydroxyapatite widely used for hard tissue repair. The designed material must have the ability to bind to the bone in order to replace or repair a bone [3]. However, hydroxyapatite is a costly and imported material. According to the Indonesian Agency for 
the Assessment and Application of Technology, imported hydroxyapatite's price reaches IDR 1 million/gram or equal to USD 100 per gram [4].

Synthetic hydroxyapatite can be made using the primary material of calcium sources from chemicals or natural materials such as limestone or bio-inorganic materials such as bones, shells, coral, or eggshells. Clamshell has been widely used as natural hydroxyapatite ingredients due to the high calcium carbonate composition to synthesize compounds containing calcium metal such as hydroxyapatite. However, in Indonesia, clamshells use are limited to handicraft materials [5]. According to Khairil, the high level of calcium carbonate in the shell can be seen in its hardness level. The harder the shell, the higher the calcium carbonate content [6].

Pugilina cochlidium is a hard-shell gastropod that lives in mangrove forest ecosystems in Indonesia [7]. Pugilina cochlidium is also found in the substrate close to the beach, muddy areas, or near estuaries [8]. Tiger snails (Babylonia spirata, L) has high economic value and considerable potential for cultivation. This snail is one of the marine animals that has long been known to the public as a source of animal protein, rich in calcium and essential amino acids (arginine, leucine, lysine), but until now, the shells or conch have not been widely used by the people of Indonesia [9]. Standard methods used to synthesize hydroxyapatite are precipitation, hydrothermal, mechanochemical, and sol-gel. The sol-gel method can produce hydroxyapatite powder with relatively homogeneous grain size, a high degree of crystallinity, low processing temperature, and the ability to produce nano-sized particles $[10,11,12]$. Based on this description, the study aimed to examine the potential of hydroxyapatite (HAp) shells of Pugilina cochlidium and tiger snails (Babylonia spirata, L) as hydroxyapatite sources for bone graft materials. This study used the sol-gel method to synthesize hydroxyapatite from Pugilina cochlidium and tiger snails (Babylonia spirata, L).

\section{MATERIALS AND METHODS}

\subsection{Materials Preparation}

The study of hydroxyapatite synthesis using the sol-gel method was carried out using Pugilina cochlidium and tiger snails (Babylonia spirata, L). Two kilograms of Pugilina cochlidium shells and two kilograms of tiger snail shells were cleaned from the snail meat using a scribe and washed. The shells were crushed using a hammer until they become small pieces. The shells were calcined at $900^{\circ} \mathrm{C}$ for 2 hours in a furnace, then cooled to room temperature. The result of calcination in the form of $\mathrm{CaO}$ is crushed using a mortar. Aluminum foil is placed on the calibrated analytical balance. The $\mathrm{CaO}$ powder of Pugilina cochlidium and tiger snails was weighed as much as 66.8 grams with an analytical balance. The $\mathrm{CaO}$ powder was then dissolved into $20 \mathrm{ml}$ of $\mathrm{HNO}_{3} 2 \mathrm{M}(2.52$ grams $)$ to form a $1 \mathrm{M}$ solution of $\mathrm{Ca}\left(\mathrm{NO}_{3}\right) 2$. The solution was then diluted $100 \mathrm{ml}$ with distillate water. The chemical reactions of the solution that are formed are:

$$
2 \mathrm{M} \mathrm{HNO}_{3}+\mathrm{Ca}(\mathrm{OH})_{2} \rightarrow \mathrm{Ca}\left(\mathrm{NO}_{3}\right)_{2}+2 \mathrm{H}_{2} \mathrm{O}
$$




\subsection{Sol-gel Method}

In the sol-gel method, a solution of ammonium was heated at $60^{\circ} \mathrm{C}$, then 181 grams EDTA added and stirred until dissolved. Calcium nitrate tetrahydrate by 129 grams, which is already dissolved in $200 \mathrm{ml}$ of distilled water, is added along with diammonium hydrogen phosphate as much as 39.83 grams and 45.2 grams of urea. The mixture is heated to $100^{\circ} \mathrm{C}$ for $3-4$ hours. The resulting gel was dried at $350^{\circ} \mathrm{C}$ under room temperature and calcined at $700^{\circ} \mathrm{C}$. The powder is mixed with the appropriate amount of diammonium hydrogen phosphate and then stirred at $90^{\circ} \mathrm{C}$ until the $\mathrm{Ca} / \mathrm{P}$ ratio is 1.67 to obtain pure hydroxyapatite.

\section{RESULTS AND DISCUSSION}

Hydroxyapatite was made by synthesis using the sol-gel method. The mixture forms a precipitate, which is then oven-dried to produce $\mathrm{CaCl}_{2}$ powder and mixed with diammonium hydrogen phosphate and urea to obtain the pure hydroxyapatite. Hydroxyapatite as a bone graft material in periodontics must meet several criteria based on its physical, mechanical, chemical, and biological properties. This study was conducted to analyze hydroxyapatite's compressive strength value as one of the mechanical properties that must be known from bone graft materials. In this study, the hydroxyapatite used was derived from the shells of Pugilina cochlidium and tiger snails (Babylonia spirata) synthesized by the sol-gel method.

In the hydroxyapatite manufacture, two heating processes are carried out for the shell powder of Pugilina cochlidium and tiger snails (Babylonia spirata); low-temperature heating using an oven and high-temperature heating using a furnace. The synthesis process begins with low-temperature heating $\left(120^{\circ} \mathrm{C}\right)$ in the oven to ensure the powder is completely dry. Heating at high temperature was carried out twice-the calcination and sintering processes. The calcination process in a furnace at a temperature of $900^{\circ} \mathrm{C}$ aims to convert calcium carbonate $\left(\mathrm{CaCO}_{3}\right)$ in the shells into calcium oxide $(\mathrm{CaO})$. In the process of calcining the snail shells at a temperature of $900^{\circ} \mathrm{C}$, impurities $\left(\mathrm{O}_{2}\right.$ gases, carbonates, and hydroxides) and other elements that cause a mass reduction are removed so that $\mathrm{CaCO}_{3}$ is converted into $\mathrm{CaO}$. Several studies have shown that heating at temperatures above $700^{\circ} \mathrm{C}$ can lead to new mineral phases, such as the formation of $\mathrm{CaO}$, as expected. The sintering process is carried out to form hydroxyapatite, and the temperature required to form the apatite phase is above $600^{\circ} \mathrm{C}$. Calcined $\mathrm{CaO}$ powder turns into calcium hydroxide $\left(\mathrm{Ca}(\mathrm{OH})_{2}\right)$ due to its high hygroscopic nature, so it quickly absorbs water vapor when it comes into contact with the atmosphere. One thing that distinguishes the sol-gel method from precipitation is the use of chemical precursors in the sol-gel method, which in this study uses a $0.1 \mathrm{M} \mathrm{HCl}$ solution. In this study, the $0.1 \mathrm{M} \mathrm{HCl}$ concentration is the optimal concentration that can produce precipitate $\mathrm{CaCl}_{2}$.

The reaction that occurs in the process: 
$\mathrm{CaCO}_{3}(\mathrm{~s}) \rightarrow \mathrm{CaO}(\mathrm{s})+\mathrm{CO}_{2}(\mathrm{~g})$

$\mathrm{CaO}(\mathrm{s})+\mathrm{H} 2 \mathrm{O}(\mathrm{g}) \rightarrow \mathrm{Ca}(\mathrm{OH})_{2}(\mathrm{~s})$

$\mathrm{Ca}(\mathrm{OH})_{2}(\mathrm{~s})+2 \mathrm{HCl}(\mathrm{l}) \rightarrow \mathrm{CaCl}_{2}(\mathrm{~s})+2 \mathrm{H}_{2} \mathrm{O}(\mathrm{l})$

$10 \mathrm{CaCl}_{2}(\mathrm{~s})+2 \mathrm{H}_{2} \mathrm{O}(\mathrm{l})+6 \mathrm{H}_{3} \mathrm{PO}_{4}(\mathrm{l}) \rightarrow \mathrm{Ca}_{10}\left(\mathrm{PO}_{4}\right)_{6}(\mathrm{OH})_{2}(\mathrm{~s})+20 \mathrm{HCl}(\mathrm{l})$

As explained in the previous chapter, the sol-gel method has received much attention due to the high homogeneity of the precursor material, lower processing temperature, nano size, and so on. The sol-gel method's main limitations are the cost of the precursor material and the time-consuming process. Research conducted by Anjaneyulu et al using the sol-gel method and with the raw material of snail shells as a source of calcium obtained hydroxyapatite measuring 60-100 nm [13]. Another study by Hanura et al with tuna bone as a calcium source obtained hydroxyapatite measuring 800- $900 \mathrm{~nm}$ [14]. This size is obtained through the Nanoblend Ball Mill process. Another study by Anggresani et al that used mackerel fish bones as a source of calcium obtained hydroxyapatite measuring 0.798 $\mu \mathrm{m}-1.069 \mu \mathrm{m}[15]$. The researchers said that this was probably caused by the non-optimal nanomill process so that the resulting particles were micrometers in size. Synthesis using the sol-gel method was also carried out by Iis Sopyan et al [16]. Using calcium nitrate tetrahydrate as a calcium source, obtained hydroxyapatite with an average size of 50-200 $\mathrm{nm}$. This study obtained hydroxyapatite measures 5,589-7,393 $\mu \mathrm{m}$ from Pugilina cochlidium snail shells and 2,614-5,410 $\mu \mathrm{m}$ from tiger snail shells.

\section{CONCLUSIONS}

In this study, the hydroxyapatite used was derived from the shells of Pugilina cochlidium and tiger snails (Babylonia spirata) synthesized by the sol-gel method. Using calcium nitrate tetrahydrate as a calcium source, obtained hydroxyapatite with an average size of 50-200 $\mathrm{nm}$. This study obtained hydroxyapatite measures 5,589-7,393 $\mu \mathrm{m}$ from Pugilina cochlidium snail shells and 2,614-5,410 $\mu \mathrm{m}$ from tiger snail shells.

\section{ACKNOWLEDGMENTS}

The authors appreciate support from Faculty of Dentistry Universitas Sumatera Utara and Research Institute of Universitas Sumatera Utara for funding these research as Letter of Agreement, Nomor: 4142/UN5.1.R/ 2020, tanggal 27 April 2020. We declared that there are no conflicts of interest concerning the contents of study.

\section{REFERENCES}

1) Munadziroh E, Rubianto M, Meizarini A. Penggunaan Bone Graft pada Perawatan Kerusakan Tulang Periodontal (Used Bone Graft for Periodontal Defect Treatment). J Dent Indones 2003;10:520-526.

2) Kumar P, Vinitha B, Fathima G. Bone grafts in dentistry. J Pharm Bioallied Sci 2013;5:S125. 
3) Agrawal K, Singh G, Puri D, Prakash S. Synthesis and characterization of hydroxyapatite powder by sol-gel method for biomedical application. J Min Mater Charact Eng 2011;10:727-734.

4) Agustiyanti RD, Azis Y, Helwani Z. Sintesis Hidroksiapatit dari Precipitated Calcium Carbonate (PCC) Cangkang Telur Ayam Ras melalui Proses Presipitasi. PhD Thesis. Riau University,2018.

5) Affandi A, Amri A, Zultiniar Z. Sintesis Hidroksiapatit Dari Cangkang Kerang Darah (Anadara granosa) dengan Proses Hidrotermal Variasi Rasio Mol Ca/P dan Suhu Sintesis. PhD Thesis.Riau University, 2015.

6) Ningsih RP, Wahyuni N, Destiarti L. Sintesis hidroksiapatit dari cangkang kerang kepah. (Polymesoda erosa) dengan variasi waktu pengadukan. J Kim Khatulistiwa 2014;3:22-26.

7) Manullang $T$, Bakti D, Leidonald R. Structure of gastropod communities at mangrove ecosystem in Lubuk Kertang village, West Berandan District, Langkat Regency, North Sumatera Province. IOP Conf Ser Earth Env. Sci, vol. 122, 2018, p. 1-6.

8) Wulandari FF. Korelasi Morfometri Cangkang Terhadap Berat Daging Siput Unam (Pugilina cochlidium) di Perairan Belawan Sumatra Utara. PhD Thesis. UNIMED, 2019.

9) Baby RL, Hasan I, Kabir KA, Naser MN. Nutrient analysis of some commercially important molluscs of Bangladesh. J Sci Res 2010;2:390-396.

10) Papapanou PN, Sanz M, Buduneli N, Dietrich T, Feres M, Fine DH, et al. Periodontitis: Consensus report of workgroup 2 of the 2017 World Workshop on the Classification of Periodontal and

11) Peri-Implant Diseases and Conditions. J Periodontol 2018;89:S173-S182.

12) Singh B, Singh R. Gingivitis-A silent disease. J Dent Med Sci 2013;6:30-3.

13) Hinrichs JE, Kotsakis G. Classification of disease and condition affecting the periodontium. In: Carranza FA, Takeii HH, Newman HG eds. Carranza's Clinical Periodontology. Missouri:WB Saunders Co, 2015: 45-67.

14) Anjaneyulu U, Pattanayak DK, Vijayalakshmi U. Snail shell derived natural hydroxyapatite: effects on NIH-3T3 cells for orthopedic applications. Mater Manuf Process 2016;31:206-216.

15) Hanura AB, Trilaksani W, Suptijah P. Karakterisasi nanohidroksiapatit tulang tuna Thunnus sp. sebagai sediaan biomaterial. J Ilmu Dan Teknol Kelaut Trop 2017;9:619-629.

16) Anggresani L. Pengaruh Waktu Sintering Terhadap Hidroksiapatit Berpori Tulang Ikan Tenggiri dengan Proses Sol-Gel. CHEMPUBLISH J 2020;5:46-56. 